\title{
Inflation and Money in Iran: An Application of Bounds Test
}

\author{
Parisa Jouhari Salmasi*, Hassan Heidari \\ Department of Economics, Urmia University,Urmia,Iran.
}

\author{
E-mail: johari.p63@gmail.com
}

\begin{abstract}
This paper provides new evidence on the long-run relationship between money and inflation of Iran economy by using quarterly data during time period of 1989:1-2007:4 and applies bounds test approach to cointegration. To investigate the long-run relationship between variables under consideration, this paper applies the bound test approach to cointegration. This method is developed by Pesaran et al. [1] and can be applied irrespective of the order of integration of the variables. The results reveal that there is a long run relationship among these variables. Also, we find that Inflation is mostly a monetary phenomenon, supporting quantity theory of money.
\end{abstract}

Keywords: Bound test, Iran, Inflation, Money.

\section{Introduction}

Iranian Central Bank 's governor announced that the annual Inflation rate has dropped below ten percent on June 2010. Infact, the sharp decline in the oil price and rising Inflation led the authorities to tighten fiscal and monetary policies in the second half of 2008/09 to this important achievement. Over the last 3 decades, however, the Iranian economy has experienced relatively high inflation with average 19.12 percent which has been generally associated with rapid persistent money growth (22.71 and 24.88 percent for M1 and M2, respectively). In 1979-80, inflation increased significantly following the 1979 Islamic revolution, but the acceleration in money growth was almost negligible (from 19.54 percent to 22.48 percent). As Bonato [2] explains, after the relatively sharp increase in the mid 1990s, Inflation declined up until the first quarter of 2006-2007, and then increased till 2008.This decline, however, did not reflect an improvement in monetary control, as both M1 and M2 continued to grow rapidly. This a vacuum of study and raising questions about the relationship between money growth and inflation in Iran. The relationship between Money and Inflation in Iran has been investigated by a number of researchers. While, Dadkhah [3] Kazeroni and Asghari [4], Parsa, 2006; Bonato [2] and Safaee, et.al, [2,6] show that monetary factors play dominant role in the long run inflation and Bahmani Osskoee [7] Nasr Esfahani and Yavari [8] Tagavi and Nakhjavani [ 9] and Darrat [10] show that other factor such as imports ,government expenditure and etc. also effect inflation. This paper re- investigate the relationship between money growth and inflation in the Quantity theory of money (QTM here after) framework. By investigating the linkage between money growth and inflation in Iran, we are going to test the validity of monetarist's stance that inflation is a monetary phenomenon. The paper differs from others in the following ways: 1) As standard unit root tests, such as Augmented Dickey Fuller (ADF) and Philips and Perron (PP) tests are biased towards the null of a unit root in the presence of structural breaks, we use Perron [11] and Lee and Strazicich [12] tests to address this issue and test the null of unit root in the series, we use the Bai and Perron [13] test to detect any structural break at an unknown change point. 2) Since existence of structural breaks may cause the series to be integration of different orders, so to investigate a long-run relation between variables under consideration, this paper applies the bounds test for cointegration within the Autoregressive Distributed Lag (ARDL) modeling approach. This method was developed by Pesaran et al [1] and can be applied irrespective of whether the underlying regressors are I(1) or I(0) or fractionally integrated. The paper proceeds as follows: section II. Provides a theoretical model for the intertemporal approach to long run relationship between Money and Inflation determination. Section III. the data investigated, IV. The Econometric Methodology of the study is presented. Section .V, contains the Results and Discussions and finally, section VI. Concludes that paper. 


\section{Theoretical Background}

A cording to Quantity theory of money, Inflation is always and everywhere a monetary phenomenon, produced in the first instance by an unduly rapid growth in the quantity of money [14]. Friedman's assertion is not that an increased money growth rate is the sole cause of inflation in the long run, just the most important cause [15]. The QTM assumes that the changes in income arise due to the changes in prices and output is always at its permanent level. Therefore, the price level is determined by the money supply via the operation of real balance effect .The simplest form of the QTM, which also known as the Cambridge equation is as follows:

$\mathrm{MV}=\mathrm{PY}$

This equation states that there is a relationship between money supply (M), velocity of money (V), prices $(\mathrm{P})$ and real income $(\mathrm{Y})$.

The Equation (1) can be written into price equation as follows:

$\mathrm{P}=\frac{\mathrm{MV}}{\mathrm{Y}}$

By taking log from both side of this equation, we can get

$$
\log P=\log M+\log V-\log Y
$$

By differentiation of Equation 3 we can get the equation for inflation such as

$$
\frac{1}{\mathrm{p}} \cdot \frac{\mathrm{dp}}{\mathrm{dt}}=\frac{1}{\mathrm{~m}} \cdot \frac{\mathrm{dm}}{\mathrm{dt}}+\frac{1}{\mathrm{v}} \cdot \frac{\mathrm{dv}}{\mathrm{dt}}-\frac{1}{\mathrm{y}} \frac{\mathrm{dy}}{\mathrm{dt}}
$$

or

$\mathrm{gp}=\mathrm{gm}+\mathrm{gv}-\mathrm{gy}$

In the equation (5) gp is inflation, gm indicates money growth, gv and gy indicate growth in the income velocity of money and output growth respectively, Laidler[16] in a simple version of QTM, assumes that the real income growth at the long-run rate and the velocity of money remains constant. Therefore the velocity and income grow slowly and this behaviour is independent of the behavior of money supply or prices .Regardless, the empirical evidence from Iran shows that the income velocity of money is not constant and the real income growth deviates from potential level of real income growth [17].It's mentionable that this paper uses quarterly data of the Iranian economy covering the period of 1989:q1-2007:q4. All data are obtained from Central Bank of Iran. We use consumer price index (CPI), Gross Domestic Product (GDP) and money stock (money plus Quasi money) for the Iranian economy as proxies for the Price level, Output,and Money, respectively. All data are seasonally adjusted except for Money. Inflation is measured by the following equation:inflation $=((\mathrm{cpi}-\mathrm{cpi}(-4)) /$ $\operatorname{cpi}(-4)) * 100)$. We have used the same approach to calculate money growth from Money, growth of the income velocity of money (v) and output growth from GDP.

\section{Econometric Methodology}

Unit root Tests are employed to test the integration level and the possible long run relationship among the variables (Dickey and Fuller (ADF), philips-perron (PP), Kwiatkowski, et.al (KPSS) and Ng- Perron (NP). To carry out unit root test with presence of any structural break, Perron [11], and suggests a modified Dicky-fuller unit root test that includes dummy variables to account for one known break. Other explain endogenous two break unit root test, and introduced a new procedure to capture two structural breaks. According to Perron [11] as Iranian economy has been subject to numerous shocks and regime shifts, ignoring the effects of any possible structural breaks can lead us to spurious unit root test results. To determine possible breaks in the data, we apply the endogenously determined multiple break test developed. Result shows the ADF, PP and NP tests with null hypothesis of unit root, reveal that Inflation, and Money growth are nonstationary at their levels, but stationary at their first differences. However, output growth and growth in the income velocity of money are stationary at their levels.As Iranian economy has been subject to numerous shocks and regime shifts, ignoring the effects of any possible structural break can lead us to spurious unit root test results. To determine possible breaks in the data, we apply the endogenously determined multiple break test developed.The results of perron [11] test indicates that in the presence of structural breaks, Money is unit root and it is integrated of order one I(1), but Inflation is stationary. To carry out unit root test with presence of any structural break, we use [11] suggests a modified DF unit root test that includes dummy variable to account for one known break. Lee and Strazicich [12] endogenous two break unit root test, and introduced a new procedure to capture two unknown structural breaks. The results of perron[11] test indicates that in the presence of structural break, Money, output growth and growth in the income velocity of money has unit root and there are integrated of order one I(1), but Inflation is stationary. The result of Lee and Strazicich [12] test, however reveals that, we can't reject the null hypothesis of unit root for Inflation, Output growth, while we reject the null hypothesis for Money growth and growth in the income velocity of money.The result of table (3), howevere reveals that in the level of significance 1 and 10 percent, we can't reject the null hypothesis of unit root for Inflation, Output and Money .but we reject the null hypothesis for 
Money growth and Money velocity. Tables 4 and 5 presents Bai and Perron's Dmax and $\operatorname{supF}_{\mathrm{T}}(\ell+1 \mid \ell)$ tests as well as Andrews [18] $\operatorname{SupF}_{\mathrm{T}}(\mathrm{m})$ test. The result revalue that there is at least one break in inflation, money growth and output growth, these results are strongly supported by CUSUM, CUSUM of square and Chow tests.The result [11] Dmax and $\operatorname{supF}_{\mathrm{T}}(\ell+1 \mid \ell)$ tests as well as Andrews [18] $\operatorname{Sup}_{\mathrm{T}}(\mathrm{m})$ test, reveal that there is at least one break in the variables under consideration. This result is strongly supported by CUSUM and Chow tests.To investigate a long run relationship between inflation and money growth, the bounds test for cointegration within ARDL (the autoregressive distributed lag) modeling approach was mainly adopted in this study. This method has definite advantages in comparison to other cointegration procedures. First, all other techniques require that the variables in the model are integrated of the same order, whereas the approach developed could be employed regardless of whether the underlying variables are I(0), I(1) or fractionally integrated. Secondly, it can be used in small sample sizes, whereas the EngleGranger and the Johansen procedures are not reliable for relatively small samples. The ARDL modeling approach involves estimating the following error correction models:

$$
\begin{aligned}
\Delta \ln Y_{\mathrm{t}}=\mathrm{a}_{0 \mathrm{y}}+ & \sum_{\mathrm{i}=1}^{\mathrm{n}} \mathrm{b}_{\mathrm{iy}} \Delta \ln \mathrm{Y}_{\mathrm{t}-\mathrm{i}}+\sum_{\mathrm{i}=1}^{\mathrm{n}} \mathrm{c}_{\mathrm{iy}} \Delta \ln \mathrm{X}_{\mathrm{t}-\mathrm{i}} \\
& +\sum_{\mathrm{i}=1}^{\mathrm{n}} \mathrm{d}_{\mathrm{iy}} \Delta \ln \mathrm{Z}_{\mathrm{t}-\mathrm{i}}+\sigma_{1 \mathrm{y}} \ln \mathrm{Y}_{\mathrm{t}-1} \\
& +\sigma_{2 \mathrm{y}} \ln \mathrm{X}_{\mathrm{t}-1}+\sigma_{3 \mathrm{y}} \ln \mathrm{Z}_{\mathrm{t}-1}+\varepsilon_{1 \mathrm{t}} \\
\Delta \ln \mathrm{X}_{\mathrm{t}}=\mathrm{a}_{0 \mathrm{x}}+ & \sum_{\mathrm{i}=1}^{\mathrm{n}} \mathrm{b}_{\mathrm{ix}} \Delta \ln \mathrm{X}_{\mathrm{t}-\mathrm{i}}+\sum_{\mathrm{i}=1}^{\mathrm{n}} \mathrm{c}_{\mathrm{ix}} \Delta \ln \mathrm{Y}_{\mathrm{t}-\mathrm{i}} \\
& +\sum_{\mathrm{i}=1}^{\mathrm{n}} \mathrm{d}_{\mathrm{ix}} \Delta \ln \mathrm{Z}_{\mathrm{t}-\mathrm{i}}+\omega_{1 \mathrm{x}} \ln \mathrm{X}_{\mathrm{t}-1} \\
& +\omega_{2 \mathrm{x}} \ln \mathrm{Y}_{\mathrm{t}-1}+\omega_{3 \mathrm{x}} \ln \mathrm{Z}_{\mathrm{t}-1}+\varepsilon_{2 \mathrm{t}}
\end{aligned}
$$

Where $\Delta$ is the difference operator, $\ln Y_{t}$ is the natural $\log$ of the dependent variable, $\ln X_{t}$ and $\ln _{\mathrm{t}}$ are the natural logs of the independent variables and $\varepsilon_{1 \mathrm{t}}$ and $\varepsilon_{2 \mathrm{t}}$ are serially independent random errors with mean zero and finite covariance matrix.

\section{Empirical Results}

Now having the fact that the variables under consideration are not in the same order of integration, a long -run equilibrium relationship will be investigated by using the bounds test for cointegration approach. Table 6 gives the results of the bounds test under three different scenarios as suggested. Table (7) gives results of the bounds test for cointegration between inflation and money growth for Iran under three different Parisa Jouhari Salmasi et. al |July.-Aug. 2012 | Vol.1 | Issue 4|07- 13 scenarios as suggested. that are $\mathrm{F}_{\mathrm{IV}}, \mathrm{F}_{\mathrm{V}}$ and $\mathrm{F}_{\mathrm{III}}$ Critical values for $\mathrm{F}$ and $\mathrm{t}$ statistics are presented in Table (2) as taken from Narayan [19] to be used in this study. Results in Table (1) suggest that the existence of a level relationship (a long-run relationship) between Money growth and Inflation.The optimal ARDL's order determined by AIC and SBC. ARDL $(4,0,0)$, model is presented below :

$\operatorname{Inf} 1.929539+0.770182 \inf (-1) 0.132787 \inf (-2)+$ $0.194541 \inf (-3)-0.471950 \inf (-4)-$

0.064501 growth $+0.059516 \mathrm{RV}+0.271219 \mathrm{RM}-$ 3.327946 Du78q2

Result shows The long-run static solution of the estimated ARDL $(4,0,0)$ model.In the long run estimates have the expected signs, but output growth and growth in the income velocity of money are insignificant in the 1,5 and 10 percent levels. The main result of this paper is that, RM (money growth), has a positive and significant effect on Inflation in long run in Iran. And Money is the most important variable that effect Inflation. In long run coefficient of Money growth very close to one and because of different is that price controls in market in recent years.In the ECM model, second and third lags of inflation with positive sign are statistically significant. This shows that the previous period growth in Inflation brings positive changes in the Inflation rate over the short-run. This implies that Inflation decisions are based on previous behavior. The changes in the RV have positive and significant effect on Inflation, over the shortrun, as its coefficient is (0.074). The estimated coefficient of changes in the RM is (0.33337) and has a positive and significant effect on Inflation rate. The Error Correction term, is statistically significant at the, 5 and 10 per cent level, with theoretically correct signs. The estimated coefficient of ecm $(-1)$ indicates that 36 percent of the disequilibrium in the Inflation is corrected immediately, in the next season. The short-run coefficient of RM is estimated (0.34), less than the long-run coefficient (0.724), therefor long run effected is strong. In the short run dummy variables have negative effect on Inflation. The result of Granger Causality test shows that, there is a unilateral relationship between Growth and RV and RM with Inflation with and without deterministic trend. The sign of the Error Correction term for inflation and money is negative and significant at the $10 \%$ and $5 \%$ level. There for money Granger causes Inflation. The findings of this study are in accordance with the results of [20,21]. In the end we do diagnostic tests, which includes testing for serial correlation, heteroscedasticity, miss-specification of functional form and normality of the residuals, these tests include Breusch-Godfrey serial correlation test, 
Table1: ADF, PP, KPSS and NP tests of unit root

\begin{tabular}{|c|c|c|c|c|c|c|c|c|}
\hline $\begin{array}{l}\text { Statistics } \\
\text { (Level) }\end{array}$ & Inflation & Lag & Growth & lag & Money growth & Lag & $\begin{array}{l}\text { Velocity of } \\
\text { money }\end{array}$ & lag \\
\hline$\tau_{\mu}(\mathrm{ADF})$ & -2.190702 & 4 & -4.920292 & 0 & -2.336405 & 0 & -2.211645 & 4 \\
\hline$\tau_{\mathrm{T}}(\mathrm{PP})$ & -2.511401 & 5 & -4.954761 & 3 & -2.708613 & 3 & -4.029815 & 3 \\
\hline$\tau_{\mu}(\mathrm{PP})$ & -2.459745 & 5 & -4.981014 & 3 & -2.538561 & 3 & -3.163695 & 4 \\
\hline$\tau \mathrm{T}(\mathrm{kpss})$ & 0.107327 & 6 & 0.150857 & 5 & 0.097419 & 6 & 0.053604 & 4 \\
\hline MZau(ng-p) & -8.69458 & 4 & -26.3487 & 0 & -7.20085 & 0 & -10.4632 & 4 \\
\hline MZtp(ng-p) & -2.07763 & 4 & -3.62964 & 0 & -1.88409 & 0 & -2.27643 & 4 \\
\hline MZaT(ng-p) & -18.6858 & 4 & -27.499 & 0 & -10.9618 & 0 & -15.8754 & 4 \\
\hline $\mathrm{MZ}_{\mathrm{Tt}}\left(\mathrm{ng} \mathrm{g}^{-p}\right)$ & -3.03473 & 4 & -3.7045 & 0 & -2.31219 & 0 & -2.79269 & 4 \\
\hline$\tau_{\mathrm{T}}(\mathrm{ADF})$ & -4.859574 & 3 & -7.612765 & 3 & -8.037686 & 0 & -6.459499 & 3 \\
\hline$\tau_{\mu}(\mathrm{ADF})$ & -4.897269 & 3 & -7.654228 & 3 & -8.092969 & 0 & -6.560921 & 3 \\
\hline$\tau(\mathrm{ADF})$ & -4.939126 & 3 & -7.708547 & 3 & -8.153582 & 0 & -6.595315 & 3 \\
\hline$\tau T(P P)$ & -7.278382 & 5 & -18.29507 & 14 & -8.048144 & 2 & -8.825503 & 2 \\
\hline$\tau_{\mu}(\mathrm{PP})$ & -7.297898 & 5 & -17.26145 & 13 & -8.102714 & 2 & -8.887978 & 2 \\
\hline$\tau(\mathrm{PP})$ & -7.340618 & 5 & -17.33791 & 13 & -8.162646 & 2 & -8.9482 & 2 \\
\hline$\tau \mu(\mathrm{kpss})$ & 0.055341 & 5 & 0.051138 & 6 & 0.051511 & 2 & 0.039322 & 2 \\
\hline 七T(kpss) & 0.050089 & 5 & 0.051305 & 6 & 0.044864 & 2 & 0.039327 & 2 \\
\hline MZaj(ng-p) & -171.077 & 3 & -0.2492 & 5 & -36.6111 & 0 & -184.576 & 3 \\
\hline MZtp(ng-p) & -9.2452 & 3 & -0.20444 & 5 & -4.13088 & 0 & -9.60063 & 3 \\
\hline
\end{tabular}

Note: $\tau_{\mathrm{T}}$ represents the most general model with a drift and trend; $\tau_{\mu}$ is the model with a drift and without trend; $\tau$ is the most restricted model without a drift and trend. Numbers in brackets are lag lengths used in ADF test (as determined by AIC set to maximum 4) to remove serial correlation in the residuals. When using PP test, numbers in brackets represent Newey-West Bandwith (as determined by Bartlett-Kernel). Both in $\mathrm{ADF}$ and $\mathrm{PP}$ tests, unit root tests were performed from the most general to the least specific model by eliminating trend and intercept across the models (See Enders, 2005: 181-199). As an alternative, the PP procedure computes a residual variance that is robust to Auto-correlation. The critical values are obtained from the ADF and PP test and for the KPSS test and from Ng and for the NP test. Tests for unit roots have been carried out in EVIEWS 6.0.

Tabel 2: Perron's unit root test

\begin{tabular}{|l|c|c|c|c|c|c|}
\hline series & Model & Break point & Dummy variable & Test statistic & Criticalvalue5\% & Result \\
\hline Inflation & $(1)$ & $1995 q 4$ & Du74q4,D(TB)74q4 & 11.9581 & -3.72 & $\mathrm{I}(0)$ \\
\hline Inflation & $(2)$ & $1995 q 4$ & Du74q4,DT74q4 & 13.66 & -3.94 & $\mathrm{I}(0)$ \\
\hline Money & $(1)$ & $1993 q 2$ & Du72q2,D(TB)72q2 & -2.53 & -3.76 & $\mathrm{I}(1)$ \\
\hline Money & $(2)$ & $1993 q 2$ & Du72q2,DT72q2 & -2.551 & -3.87 & $\mathrm{I}(1)$ \\
\hline
\end{tabular}

Notes: Models (1) and (2) refer to the models specified in Perron. The dummy variables are specified as follows: D(TB) 74q4 and D(TB) 72q2 are impulse dummy variables with zeros everywhere except for a one in 1995, and 1993. DU74q4 and DU72q2 are 1 from 1995 and 1993 onwards and 0 otherwise. DT74q4 and DT72q2 are 0 before 1995 and 1993 and t-TB otherwise. Critical values for the levels are provided. Critical values for the first differences. For the first differences only impulse dummy variables were included in the regression. Impulse dummy variables, that is those with no long-run effect, do not affect the distribution of the test statistics.

Table 3: Lee and Strazicich two structural break unit root test

\begin{tabular}{|l|c|c|c|c|}
\hline \multicolumn{1}{|c|}{ Variable } & TB1 & TB2 & K & t-statistic \\
\hline lgdp & $1992 q 1$ & $2000 q 4$ & 0 & $-7.5084^{* *}$ \\
Inflation & $1993 q 2$ & $1995 q 4$ & 5 & $-7.5601^{* *}$ \\
Money growth & $1995 q 4$ & $2000 q 1$ & 3 & -5.7683 \\
Money velocity & $1992 q 4$ & $2002 q 4$ & 6 & -5.3085 \\
\hline
\end{tabular}

Note: 1) The critical values at $1 \%, 5 \%, 10 \%$ are $-5.823,-5.286$ and -4.989 , respectively (Lee and Strazicich,2003) 2 )** indicates that the corresponding null is rejected at the $1 \%, 5 \%$ and $10 \%$ level of significant.

ARCH heteroskedasticity test and CUSUM and CUSUM of Squares stability tests (Figure 1).
These tests indicate that there aren't any serial correlation, heteroskedasticity and structural instability in the residual of the inflation function. 
Table 4: Structural break tests of inflation

\begin{tabular}{|l|c|c|c|c|c|}
\hline \multicolumn{1}{|c|}{ Inflation } & Value of test & Critical value10\% & Critical value5\% & $\begin{array}{c}\text { Critical } \\
\text { value2.5\% }\end{array}$ & $\begin{array}{c}\text { Critical } \\
\text { value1\% }\end{array}$ \\
\hline supfT(1) & 0.902 & 7.04 & 8.58 & 10.18 & 12.29 \\
\hline supFT (2) & 2.1728 & 6.28 & 7.22 & 8.14 & 9.36 \\
\hline supF T (3) & 1.4528 & 5.21 & 5.96 & 6.72 & 7.6 \\
\hline supF T (4) & 1.1743 & 4.41 & 4.99 & 5.51 & 6.19 \\
\hline supF T (5) & $6.193^{*}$ & 3.47 & 3.91 & 4.34 & 4.91 \\
\hline UD max & 6.193 & 7.46 & 8.88 & 10.39 & 12.37 \\
\hline WDmax & - & 12.5644 & $13.5897^{*}$ & 14.5264 & 15.5014 \\
& & $(8.2)$ & $(9.91)$ & $(11.67)$ & $(13.83)$ \\
\hline supF(2|1) & 1.5469 & 7.04 & 8.58 & 10.18 & 12.29 \\
\hline supF(3|2) & 1.7468 & 8.51 & 10.13 & 11.86 & 13.89 \\
\hline supF(4|3) & 0.1125 & 9.41 & 11.14 & 12.66 & 14.8 \\
\hline supF(5|4) & 0 & 10.04 & 11.83 & 13.4 & 15.28 \\
\hline
\end{tabular}

Table5: Structural break tests of money growth

\begin{tabular}{|l|c|c|c|c|c|}
\hline \multicolumn{1}{|c|}{ Money growth } & Value of test & Critical value10\% & Critical value5\% & $\begin{array}{c}\text { Critical } \\
\text { value2.5\% }\end{array}$ & $\begin{array}{c}\text { Critical } \\
\text { value1\% }\end{array}$ \\
\hline supfT(1) & 8.1292 & 7.04 & 8.58 & 10.18 & 12.29 \\
\hline supFT (2) & $9.7525^{*}$ & 6.28 & 7.22 & 8.14 & 9.36 \\
\hline supF T (3) & $31.4475^{*}$ & 5.21 & 5.96 & 6.72 & 7.6 \\
\hline supF T (4) & $27.5361^{*}$ & 4.41 & 4.99 & 5.51 & 6.19 \\
\hline supF T (5) & $20.7713^{*}$ & 3.47 & 3.91 & 4.34 & 4.91 \\
\hline UD max & $31.4475^{*}$ & 7.46 & 8.88 & 10.39 & 12.37 \\
\hline WDmax & - & 43.9579 & $47.3467^{*}$ & 50.8744 & 54.6719 \\
& & $(8.2)$ & $(9.91)$ & $(11.67)$ & $(13.83)$ \\
\hline supF(2|1) & 3.4822 & 7.04 & 8.58 & 10.18 & 12.29 \\
\hline supF(3|2) & $11.6546^{*}$ & 8.51 & 10.13 & 11.86 & 13.89 \\
\hline supF(4|3) & 8.3 & 9.41 & 11.14 & 12.66 & 14.8 \\
\hline supF(5|4) & 0 & 10.04 & 11.83 & 13.4 & 15.28 \\
\hline
\end{tabular}

Table 6: F statistic critical values of bound test

\begin{tabular}{|l|c|c|c|c|c|c|}
\hline \multicolumn{1}{|c|}{$\mathbf{K}=3$} & \multicolumn{2}{c|}{$\mathbf{1 0 \%}$} & \multicolumn{2}{c|}{$\mathbf{1 \%}$} \\
\hline & $\mathrm{I}(0)$ & $\mathrm{I}(1)$ & $\mathrm{I}(0)$ & $\mathrm{I}(1)$ & $\mathrm{I}(0)$ & $\mathrm{I}(1)$ \\
\hline $\mathrm{F}_{\mathrm{IV}}$ & 3.11 & 3.90 & 3.624 & 4.488 & 4.808 & 5.786 \\
\hline $\mathrm{F}_{\mathrm{V}}$ & 3.618 & 4.630 & 4.253 & 5.333 & 5.698 & 6.970 \\
\hline $\mathrm{F}_{\text {III }}$ & 2.838 & 3.898 & 3.408 & 4.55 & 4.725 & 6.08 \\
\hline
\end{tabular}

Critical values are from Narayan [19] Note: $\mathrm{k}$ is the number of regressores for dependent variable in ARDL model, $\mathrm{F}_{\text {IV }}$, represents the $\mathrm{F}$ statistic of the model with unrestricted intercept and restricted trend, Fv, represents the F statistic of the model with unrestricted intercept and trend, and $\mathrm{F}_{\mathrm{III}}$, and represents the $\mathrm{F}$ statistic of the model with unrestricted intercept and no trend. The lag length (p) for this test is based on Schwarz-

Bayessian (SBC) and Akike information criteria (AIC). the best choice of lag order is four.

Table 7: Bounds test of cointegration

\begin{tabular}{|l|l|l|l|l|l|}
\hline \multirow{2}{*}{ Variables } & \multicolumn{3}{c|}{ With deterministic trend } & \multicolumn{2}{c|}{ without deterministic trend } \\
\hline \multirow{2}{*}{ Finf(inf | gm,gy,gv,du78q2) } & $\mathrm{F}_{\mathrm{IV}}$ & $\mathrm{F}_{\mathrm{V}}$ & $\mathrm{tV}_{\mathrm{V}}$ & $\mathrm{F}_{\mathrm{III}}$ & $\mathrm{t}_{\mathrm{III}}$ \\
\cline { 2 - 6 } & $9.25021^{*}$ & $11.56228^{*}$ & -6.740912 & $11.7893^{*}$ & -6.806762 \\
\hline
\end{tabular}

Notes: Akaike Information Criterion (AIC) and Schwartz Criteria (SC) were used to select the number of lags required in the cointegration test. $\mathrm{F}_{\mathrm{IV}}$ represents the $\mathrm{F}$ statistic of the model with unrestricted intercept and restricted trend. $\mathrm{F}_{\mathrm{V}}$ represents the $\mathrm{F}$ statistic of the model with unrestricted intercept and trend, and $\mathrm{F}_{\mathrm{III}}$ represents the $\mathrm{F}$ statistic of the model with unrestricted intercept and no trend . Note: H0: no existence long run. * indicates that the statistic falls outside the upper bound at all levels.

Table 8: Long-run static solution of the estimated ARDL $(4,0,0)$ model

\begin{tabular}{|l|c|c|c|}
\hline Variables & Coefficients & Standard errors & T-Ratio (Prob) \\
\hline GROWTH & -0.172261 & 0.174108 & $-0.989392(0.3258)$ \\
\hline RV & 0.158948 & 0.104468 & $1.521560(0.1325)$ \\
\hline RM & 0.724333 & 0.2036 & $3.557633(0.0007)$ \\
\hline intercept & 5.153136 & 5.174162 & $0.995936(0.3226)$ \\
\hline
\end{tabular}


Table 9: Error correction representation for the Selected ARDL Model

\begin{tabular}{|l|c|c|c|}
\hline \multicolumn{1}{|c|}{ ARDL (1,0,0,0) selected based on SBC, dependent variable is Dinf. } \\
\hline \multicolumn{1}{|c|}{ Regressors } & Coefficient & Standard error & T-ratio(prob) \\
\hline DInf(-1) & 0.145564 & 0.098646 & $1.475611(0.145)^{*}$ \\
\hline DlInf(-2) & -0.287428 & 0.0999574 & $2.886571(0.0053)^{*}$ \\
\hline DInf(-3) & 0.457022 & 0.107879 & $4.2364445(0.0001)^{*}$ \\
\hline DRM & 0.363176 & 0.138486 & $2.622469(0.0109)^{*}$ \\
\hline DGrowth & -0.032027 & 0.0821 & $-0.390099(0.6978)^{* *}$ \\
\hline DRv & 0.033416 & 0.060935 & $0.548381(0.5854)$ \\
\hline DDu78q2 & -1.838648 & $2 / 624759$ & $-0.700502(0.4862)^{* *}$ \\
\hline DIntercept & -0.026461 & 0.306242 & $-0.086406(0.9314)$ \\
\hline \multicolumn{1}{|c|}{ Ecm(-1) } & -0.367961 & 0.066161 & $-5.561559(0.000)$ \\
\hline R-Squared=0.43 & R-Bar-Squared=0.35 & F-stat= 5.823872(0.000015) & \\
\hline SER=2.565949 & RSS=414.7978 & DW=1.72 & \\
\hline AIC $=4.839002$ & SBC=5.123585 & & \\
\hline
\end{tabular}

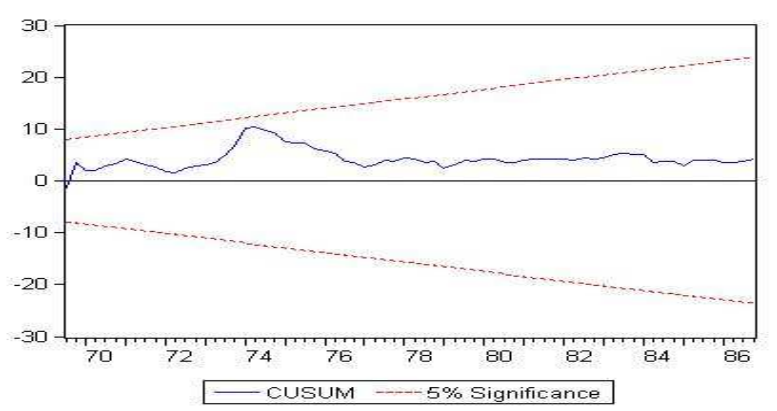

Fig. 1: CUSUM test

\section{Conclusions}

This paper attempts to re-investigate the causal relationship between Inflation and Money growth for the Iranian economy, by employing, the bounds test approach to cointegration, in the

\section{References}

1. Pesaran H, Shin Y, Smith RJ (2001) Bounds testing approaches to the analysis of level relationships. J. Applied Econometrics 16:289-326.

2. Bonato L (2007) Money and Inflation in the Islamic Republic of Iran," IMF Working Paper, International Monetary Fund.

3. Dadkhah K (1995) The Inflationary Process of the Iranian Economy. Int. J. Middle East Study, 17:

4. Kazeruni B Asghari (2002) Classical Inflation test Model in Iran: Cointegration approach,"J. Trade Research. 23.

5. Parsa "Identify sources of Inflation in Iran," M.A dissertation, university of Shiraz, 2006.

6. Safaee L, Komyjani A, Mehrara M (2009) Analysis of the role of factors on inflation in Iran. Vector Auto Regressive approach M. A, "Dissertation. Tehran University.

7. Bahmani-Oskoee M (1995) Sources of inflation in post revolutionary Iran. Int. Economic Journal 9(2).

8. Nasr-Esfahan, Yavari IR (2003) Nominal and real factors that effective inflation in Iran: Vector auto-regressive approach. J. Economic Research 16:69-99.

9. Tagavi A, Nakhjavani (2003) Stagflation in Iran economy. J. Economic Research 9:13-70.
Quantity theory of money. The bounds test results reveal that a long-run cointegration relationship exist between Money growth and Inflation. Moreover our results show stability relationship between two variables and in the long run 1 percent increase in Money growth cause to increase 72 percent in Inflation in Iran, which means Money is the most important variable that effect inflation in long run. By review this relationship, we can be attributed apparent dissociation in related to inflation and Money in recent years, factors such as decrease in income velocity of money because of decrease in inflation expectations, in the third development plan and improvement in oil prices in world oil markets.

10. Darrat F (1987) The inflationary process of iranian economy: A re-examination of the evidence.Int. J. Middle East Study 19, .

11. Perron (1990) Testing for a unit root in a time series with a changing mean. J. Business and Economic Statistics 8:15362 .

12. Lee, Strazicich MC (2003) Minimum Lagrange multiplier unit root test with two structural breaks. Review of Economics and Statistics 85:1082-9.

13. Bai J, Perron P (2003) Computation and analysis of multiple structural change models. J. Applied Econometrics 18:1-22.

14. Friedman $M$ (1968) Inflation in dollars and deficits. $E$ nglewoodC liffs, NJ: PrenticeH all, 1968, pp. 17-20

15. Friedman M, Rose D (1980) Friedman, "Free to choose". New York: H arcourt Bracej ovanovich.

16. Laidler D (1971) Money and Macroeconomics; the Selected Essays of David Laidler," UK: Edward Elgar.

17. Shakeri A Inflation in the nature of Iran's economy," P.G.D. dissertation, Shahid Beheshti university, 2000.

18. Andrews DWK9 (1993) Tests for parameters Instability and structural change with unknown change point. Econometrica 61:821-56. 


\section{Available online at www.managementjournal.info}

19. Narayan PK (2005) The saving and investment nexus for china: evidence from cointegration tests. Applied Economics 37:1979-90
20. Hosseini S, Mohtasham IT (2008) Relationship between money growth and inflation in Iran, rupture or stability. Quarterly Economic Research 3:21-4.

21. Komyjani A (2006) Review to Iran economy. J. Ravand, Central Bank of Iran.issus 48. 